\title{
Coercion for the ages? A thousand years of parallel inchoative histories for the French passé simple and passé composé \\ Patrick Caudal $^{*}$
}

\begin{abstract}
This paper investigates the diachronic evolution of so-called aspectual coercion (de Swart 1998, Bary \& Egg 2012) in French, with respect to two major tenses, namely the simple past (passé simple) (PS) and compound past (passé composé) (PC); it will more specifically bear on cases of inchoative readings. Throughout a study spanning several diachronic stages and capitalizing on earlier work (Caudal 2015a, Caudal 2015b, Caudal, Burnertt \& Troberg 2016), it will be shown that the PC and the PS exhibit striking differences in their acquisition of inchoative coercions, with the PC consistently lagging behind the PS in some respects. Initially, at the Old French period, the PC was totally deprived of any coercive power w.r.t. states, whereas the PS already had a broader and better established inchoative coercive capability. But across subsequent stages of the language, the PS gradually increased its inchoative potential at a steady pace although it seems to retain some difficulties with certain types of stative utterances, especially those denoting individual-level states, and locative/posture structures. While the PC has often been claimed to have largely replaced the PS, I will here show that even in Modern French, the PC seems to still have a noticeably lesser 'inchoativizing power' than the PS. In order words, in spite of nearly a thousand years of parallel evolution and semantic convergence, the initial semantic gap between the two forms still hasn't been bridged. I will suggest that these consistent differences should lead us to consider so-called inchoative coercion as a distinctly conventionalized type of meaning expansion mechanism - rather than a simple matter of overcoming the violation of some aspectual semantic restriction.
\end{abstract}

Keywords. aspectual coercion; formal semantics; diachrony; language change; tense; aspect; French language; passé composé; passé simple; corpus study

1. Introduction. Ever since it was formulated in theoretical and formal terms, the notion of coercion has been both widely used, and hotly debated. I will specifically focus here on a subtype of coercion, namely so-called aspectual coercion, as defined in de Swart (1998); it is all the more relevant to the present investigation that it is specifically designed to model the semantics of French tenses. Aspectual coercion is based on the broad intuition that tenses denote functions over event predicates, and are endowed with aspectual semantic selectional restrictions, i.e. select for predicates denoting particular Aktionsart types (or semantic types of event descriptions, if one dislikes the notion of Aktionsart). Given this definition, type mismatches may arise, when a tense's aspectual selectional restriction borne by a tense is not met by the denotation of verb it combines with. An additional tenet of the theory is that the aspectual denotation of tenses can be - and should be - centrally defined in terms of said selectional restrictions. This is in line with sometimes with numerous independent empirical generalizations and theoretical claims, even in informal works, about so-called 'affinities' between aspectual classes of tenses (see Garey 1957,

\footnotetext{
*This research has been supported by the Labex Empirical Foundations of Linguistics (Agence Nationale de la Recherche programme Investissements d'Avenir, ANR-10LABX-0083) project (MEQTAME subproject). Author: Patrick Caudal, CNRS \& Université de Paris (pcaudal@linguist.univ-paris-diderot.fr).
} 
Kamp \& Rohrer 1983, Smith 1991, a.o. for the idea that so-called imperfective tenses are naturally compatible with atelic predicates, while perfective tenses are naturally compatible with telic predicates.) As defined in de Swart (1998), aspectual coercion is a non-destructive type-shift operation, triggered by type-mismatch, causing the initial denotation of a verb - namely a subdiscourse representation structure (DRS) - to become 'embedded' within a novel sub-DRS, under a coercion operator. De Swart crucially considers the opposition between two configurations under which aspectual coercion arises:

(i) Instances of coercion triggered by purely aspectual morphology - e.g. in English, the -ing progressive morphological exponent, which directly denotes an aspectual operator, inherently capable of type-shifting 'inappropriate' input types - cf. the ability of the English progressive to induce non-culminating (i.e. atelic) readings of telic event predicates

(ii) 'Covert' coercion operators, triggered when so-called aspect-sensitive, synthetic tenses (i.e. not possessing any allegedly purely aspectual exponent/morphological element) are combined with event predicate types violating their Aktionsart selectional restrictions. These are introduced in the logical form via type mismatch rules present in the semantic system, but not directly denoted by any morphological element. The French imparfait thus also produces 'detelicizing' coercion effects with telic event predicates, but not in the same manner as the English past progressive.

This dichotomy is, in fact, deeply problematic, if one establishes that the morphological make-up of so-called analytic tenses is not compositional, i.e. that there is no such thing as 'purely aspectual exponents' in their morpho-syntax. While I believe that it can be shown to be the case on the basis of diachronic data, ${ }^{1}$ this does not matter for the purposes of the present investigations (see also Bonami 2002 for other empirical and theoretical objections to a type of coercion operators not directly controlled by forms.)

An obvious solution to these objections would be to opt for a different type of coercion theory, for instance à la Moens \& Steedman 1988, whereby all tenses receive the same type of coercion mechanisms, regardless of whether they are synthetic or analytic. Maybe such a theory could be engineered so as to make coercion strictly form-controlled, for instance. So, let's assume some theory of aspectual coercion capable of overcoming these already known (or relatively evident) challenges. Its actual form matters little, as long as it conforms to the most basic tenet any theory of coercion should be based upon, namely that type mismatches (here, violations of aspectual selectional restrictions of tenses) should trigger some aspectual type-shift. This can be seen as a case of aspectual meaning enrichment.

The objective of this paper is to confront such a theory with novel, historical facts, stemming from the careful investigation of phenomena commonly treated in terms of aspectual coercion, and to determine whether a theory of aspectual coercion is compatible with a detailed study of the aspectuo-temporal evolution of tense forms. I will specifically focus here on the evolution of so-called inchoative readings of two French tenses, namely the passé simple and the passé composé. Inchoative readings will be understood here in relation to aspectual selectional restrictions

\footnotetext{
${ }^{1}$ Thus, it is well-known that the semantics of so-called grammaticalized perfects is non-compositional. See e.g., Carey 1994, for the development of the 'subject-agentive' meaning of the perfect in Old English, which cannot be associated with any particular subcomponent of the perfect. The overall tense thus became non-compositional at that time - it became a complex aggregate of temporal and aspectual conditions, none of which can be really legitimately 'paired up' with any particular morphological component. See also e.g., Condoravdi \& Deo 2014.
} 
attached with tenses. Inchoative readings of state or activity denoting verbs involve a transitional reading of an otherwise non-transitional event predicate, cf. e.g., (1):

$\begin{array}{lll}\text { Jean fut } & \text { soudain } & \text { malade. } \\ \text { Jean be-PS.3sg } & \text { suddenly } & \text { sick. } \\ \text { 'All of a sudden, Jean became sick' } & \end{array}$

The passé simple, being a perfective tense, is predicted to normally select for telic/change-ofstate event predicates. As être malade does not describe such a predicate, an aspectual coercion must arise to accommodate the type mismatch here encountered, resulting in être malade coming to describe an incipient event leading up to a state of sickness (something like 'become sick'). Such would be the basic doxa for a coercion-based analysis of (1).

I will now undertake to demonstrate whether or not the very idea of aspectual coercion as a kind of accommodation mechanism, compensating for some selectional restriction being violated, is compatible with a detailed, historical study of inchoative coercions in French. Section 2 will establish some novel, and I think crucial, facts concerning stative utterances in the passé composé during the Old French period. Section 3 will be dedicated to several small corpus studies of various semantic types of stative utterances, and how they can - or cannot - receive inchoative readings with the passé composé and passé simple in Modern French. Finally, section 4 will return to the theoretical and formal matter at hand: are historical facts compatible with a classic coercion-based analysis of inchoativity in French, i.e. revolving around type-mismatches?

2. Old French slices of the passé simple and passé composé. It is well known from previous works dedicated to the diachrony of the French tense-aspect system (see e.g., Martin 1971, Wilmet 1970), that the Old and Middle French period was a key moment in its history, especially w.r.t. to the passé simple and the passé composé, which both underwent massive changes around that time. Roughly speaking, the passé simple (PS, henceforth) was highly polyfunctional during much of the Old French period, as it was capable of not only perfective, but also imperfective and resultative (i.e. perfect-like) readings (Foulet 1920) - very much like the simple past in some dialects of English. However, from the $14^{\text {th }} \mathrm{C}$. onwards, the PS saw its semantics consistently narrowing towards its current, perfective-only meaning, slowly shedding its imperfective and perfect readings inherited from the Latin perfectum. ${ }^{2}$ It thus underwent a gradual semantic attrition (see Caudal 2015a for details), in three stages (roughly speaking): (a) starting from an initial restriction to stative sentences in early Old French texts (it was not attested with activities), and it then (b) became gradually restricted to existential constructions and individual-level predicates $\left(13^{\text {th }}-14^{\text {th }}\right.$ century). And (c) final attestations of this use (end of $15^{\text {th }} \mathrm{c}$. / early $16^{\text {th }} \mathrm{c}$.) were limited to genealogical/profession-ascription individual-level utterances (Caudal 2015b)

$\begin{array}{lll}\text { Mon pere } \quad \text { fut } & \text { ung } \\ \text { My father } & \text { be-PS.3sg } & \text { a } \\ \text { 'My father was a slipper-maker' }\end{array}$

savetier.

slipper-maker.

(Middle Fr., 15th c., Sotties, in Wilmet 1970)

This semantic ambivalence of the PS until the $16^{\text {th }}$ century is important, in the sense that the meaning of this tense did not select specifically for non-stative predicates at the time - so inchoative coercions, if they occur at all, must be derived from discourse-structural and other contextual

\footnotetext{
${ }^{2}$ See Caudal (2015b), Caudal \& Vetters (2007). The literature on this topic is fairly minimal; semantic attrition is rarely regarded as an important phenomenon. On the aspectual polyfunctionality of the Latin perfectum, see Haverling 2010a, b.
} 
cues (e.g. discourse connectives, specific types of discourse relations); some amount of contrast with the inchoative potential of the PS in Modern French is certainly predicted to exist. Similarly, Caudal (2015a) demonstrates that the PC did not have bona fide perfective uses prior to the $15^{\text {th }}$ c.; so its inchoative potential with stative utterances should vary through time.

I found a first confirmation of this hypothesis while conducting an annotated corpus study of PC forms in the Roland $\left(12^{\text {th }}\right.$ c.) for an unrelated purpose (see Caudal, Burnett \& Troberg 2016. The data collected suggested that this tense was seldom attested with atelic utterances in early Old French, unless quantificational/aspectuo-temporal adverbials intervened. The initial pilot study involved 600 randomly selected past participials ${ }^{3}$ forms, extracted from the Roland in the Base du Français Médiéval corpus (BFM, http://txm.bfm-corpus.org/). PC forms were manually identified in this sub-corpus, yielding 257 instances of PC-marked utterances. These forms were then annotated for tense and aspect interpretation, and 29 utterances involving seemingly atelic verb constellations in the sense of Smith (1991) (here a verb combined with all its valents) were found, with one surprising characteristic: they were all associated with kind of bounding or maximizing adverbial forcing, cf. examples (3-5), and Table 1.

Set

anz

tuz pleins

\section{ad}

Seven year-pl all-pl full-pl

'He stayed in Spain for seven years'
have-PR.3sg

estet

be.loc-PP

en Espaigne

in Spain

(Roland, v. 2)

\section{Ensemble \\ avum \\ estet}

Together have-PR.1pl

be.loc-PP

'We've been together for a very long time'

e anz and year-pl

e $\quad \operatorname{dis}[\ldots]$

and day-pl

(Roland, v 2028)

$\begin{array}{llll}\text { En la cort al } & \text { rei } & \text { mult } \\ \text { In the court of.the } & \text { king } & \text { much }\end{array}$
'At the king's court you have stayed for long'

\section{$\mathrm{Si}$ lungement tut tens m'avez}

So long

all time 1sg.OBL.have-PR.2pl

'You have constantly served me for so many years!'

ested $(\ldots)$

PRO.LOC have.PR.2pl be.loc-PP

(Roland, v. 350-35)

\section{servit!}

serve-PP

None of these examples involve any kind of perfective inchoative reading; (4)-(6) are perfectlike uses of the $\mathrm{PC}$, and (3) is a durative perfective reading involving a temporal measure phrase ('set ans') - not an inchoative use of the PC.

\begin{tabular}{lcccccccccc}
\hline $\begin{array}{l}\text { Aspectual } \\
\text { classes }\end{array}$ & $\begin{array}{c}\text { Ato- } \\
\text { mic } \\
\text { telic }\end{array}$ & $\begin{array}{c}\text { Inchoa- } \\
\text { tive } \\
\text { activities }\end{array}$ & $\begin{array}{c}\text { Non-ato- } \\
\text { mic telic }\end{array}$ & $\begin{array}{c}\text { Various } \\
\text { Changes-of- } \\
\text { State }\end{array}$ & $\begin{array}{c}\text { Semel- } \\
\text { factives }\end{array}$ & $\begin{array}{c}\text { Bounded } \\
\text { activities }\end{array}$ & $\begin{array}{c}\text { Maxed } \\
\text { activities }\end{array}$ & $\begin{array}{c}\text { Bounded } \\
\text { states }\end{array}$ & $\begin{array}{c}\text { Maxed } \\
\text { states }\end{array}$ & Total \\
Instances & 177 & 5 & 29 & 6 & 6 & 5 & 26 & 2 & 1 & 257 \\
\hline Percentage & $68,8 \%$ & $1,9 \%$ & $11,28 \%$ & $2,33 \%$ & $2,33 \%$ & $1,95 \%$ & $10,12 \%$ & $0,78 \%$ & $0,39 \%$ & $100 \%$ \\
\hline
\end{tabular}

Table 1. Distribution of event predicate aspectual types in a sub-corpus of the Roland

Following this accidental finding, I searched the remaining 342 participial forms in the Roland; I found an additional 15 atelic utterances in the $\mathrm{PC}-4$ quantified states, and 11 quantified activities/pluractional dynamic events. They are all associated with some kind of bounding or maximizing expression, effectively forcing them to denote quantized event predicates in the sense of Krifka (1998) - thus, they do not qualify as bona fide activity or state-denoting utterances.

\footnotetext{
${ }^{3}$ The text comprises 942 past participial forms, out of which I estimate that roughly $40 \%$ are PC forms.
} 
It should be noted that in contrast, other tenses - in particular the PS - offer abundant examples of bona fide atelic utterances, without the necessity of involving quantizing expressions. I effected a short comparison with a passé simple (PS) baseline, involving all the PS forms of estre ('be', 66 occurrences) and aveir ('have', 39 occurrences). As Table 24 shows, stative PS utterances in the Roland are not biased towards quantized readings, even if we leave aside imperfective readings; non-quantized stative utterances are better represented, and inchoative readings are rare (less than 5\%). This suggests the existence of a strong semantic difference between the PC and the PS with respect to (i) atelic utterances (only the PS can combine with them) and (ii) to a lesser extent, inchoative readings. It should be mentioned that inchoative utterances found either involved a special causative structure, with pronominal en (en referring back to a previously introduced causal event) (7), or with a bi-clausal structure explicating the causal link (8). As we will see, this kind of 'contextualizing', backing-up material is essential for inchoative readings of stative utterances to be felicitous. $\begin{array}{lllllll}\text { (7) li } & \text { quens } & \text { Guenes en } & \text { fut } & \text { mult } & \text { anguisables } \\ & \text { And the count } & \text { Ganelon from.it } & \text { be-PS.3sg much } & \text { anguished }\end{array}$ 'And this filled count Ganelon with anguish' $\quad$ (Roland, v. 280)

(8) Tant chevalchet qu'en Sarraguce fut. So.much ride-PR.3sg that.in Zaragoza be-PS.3g. 'He rode for a long time, so that he reache Zaragoza' (Roland, v. 2818)

\begin{tabular}{lccccccc}
\hline $\begin{array}{l}\text { Aspectual } \\
\text { readings }\end{array}$ & $\begin{array}{c}\text { Perfect } \\
\text { quantified }\end{array}$ & $\begin{array}{c}\text { Result } \\
\text { perfect }\end{array}$ & $\begin{array}{c}\text { Existential } \\
\text { perfect }\end{array}$ & $\begin{array}{c}\text { Inchoative } \\
\text { perfective }\end{array}$ & $\begin{array}{c}\text { Other } \\
\text { perfective }\end{array}$ & Imperfective & Total \\
\hline Instances & 3 & 5 & 16 & 5 & 15 & 61 & 105 \\
\hline Percentages & $2,86 \%$ & $4,76 \%$ & $1,52 \%$ & $4,76 \%$ & $1,43 \%$ & $58,1 \%$ & $100 \%$ \\
\hline
\end{tabular}

Table 2. Event predicate type and ester-PS and aveir-PS in the Roland

A further validation study was conducted on the $13^{\text {th }} \mathrm{c}$. Conte del Graal ('Perceval'). For want of space, details are omitted, but from 1,500 randomly selected participial forms, 390 PC utterances were manually identified and annotated; 20 utterances with atelic (stative) verbs $(5,19 \%)$ in the PC were found. Like in the Roland, all were associated with quantizing modifiers, cf. (910 ), and no bona fide inchoative readings were found.

$\mathrm{Au}$ mangier ont mout sis

At.the eat-INF have.3pl.PR much sit-PP. (sit-PC, perfective durative) 'They sat having dinner for a long time'. $\quad$ (Conte, 368b, v. 1919)

$\begin{array}{llll}\text { Dameisele, je croi } & \text { a ces ansaignes [...] } \\ \text { Young.lady, I believe-1sg.PR } & \text { at these flags } \\ \text { que chevalier a } & \text { eü } & \text { ci. (be-PC, existential) } \\ \text { that knight have.3sg.PR } & \text { have-PP here. }\end{array}$

'My lady, because of these flags, I think a knight has been here' (Conte, 363f, v. 787)

Again, inchoative readings in this text are only found with PS forms - and these uses remain marginal. Both in the Roland and in the Perceval, perception verbs (such as entendre 'hear', cf.

4 'Bare existential' readings correspond to (existential) perfect interpretations of the PS, deprived of any temporal modifiers. Similar readings of the PC seem to be available from the $13^{\text {th }} \mathrm{c}$. onwards. Note also that predictably, a substantial (66\%) part of estre utterances in the PS receive an imperfective meaning. In line with observations made in Caudal (2015b), the majority of these imperfective uses appear to be stage-level denoting. 
(11)) or psych verbs/constructions (grant duel avoir 'to suffer from a great affliction', cf. (12)) were found to appear freely in the $\mathrm{PC}$, but only with a transitional, perfective change-of-state reading, or a related resultative reading - never with a truly stative interpretation. These verbs/constructions are inherently polyfunctional, aspectually speaking, and unless combined with the présent or the imparfait, they do not seem to have true stative denotations.

(11) Et quant li fos l'a entendu, si saut an piez et... And when the fool him-have.PR.3sg hear-PP, CONJ jump-PR.3sg on feet and... 'And when the fool heard him, he jumped on his feet and...' (Perceval, 376c, v. 4054)

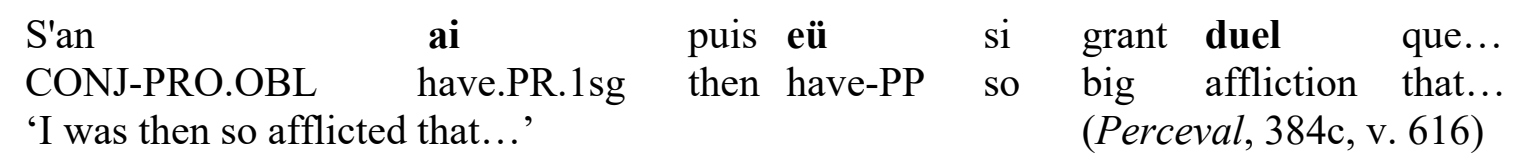

3. (Early) Modern slices of the passé simple and passé composé. Let us move a few centuries forward, and look at the situation found in Early Modern and Modern French w.r.t. to the respective inchoative capabilities of the PC and PS. The remainder of this paper will focus on utterances denoting stative predicates, and their inchoative readings in combination with the PC and PS; it comprises several small quantitative forays conducted on the Frantext (https://www.frantext.fr/) Classical French (1650-1799), comprising 43,322,657 words, and Modern French (1800-1979) sub-corpora, comprising 149,304,319 words. These corpora overwhelmingly consist of fiction genres - which is in line with the OF data studied before. So this investigation is really about formal narrative uses of the PS and PC.

It is a well-known fact from Renaissance / Early Modern Grammars of French that the PS was gradually excluded from conversational use from the $16^{\text {th }} \mathrm{c}$. onwards, particularly in Ile-deFrance French; its use had become a hallmark of 'provincialism' (the distinction held until recently between Ile-de-France/standard French, and various Western and Easterm French dialects, where the PS had retained 'conversational' uses). See Caudal \& Vetters (2007) for a detailed discussion, and some corpus observations. Of course, in a reverse movement, as the PS lost ground, the PC steadily gained some. It soon became the primary tense for conversational narratives, ${ }^{5}$ and has been argued to have become fully 'perfectivized' some time around the $17^{\text {th }} / 18^{\text {th }} \mathrm{c}$. (Caudal \& Vetters (2007).

Most importantly, it appears that the PC and PS reached similar rates of occurrences with stative verbs in the $17^{\text {th }}-18^{\text {th }}$ c. $^{6}$ Simultaneously, the PC ceased requiring a quantifying expression to be compatible with such a verb. And most importantly for the present investigation, it had become capable of inchoative readings with stative predicates, cf. (13).

(13) Je viens de recevoir votre lettre du 17 de ce mois (...) et le hasard a été bon homme pour le coup. (R. BUSSY-RABUTIN, Les Lettres de messire Roger de Rabutin, t3, 1672, p. 523)

'I have just received your letter dated on the $17^{\text {th }}$ of this month, and chance was kind in this instance'

\footnotetext{
${ }^{5}$ On the use of the PC vs. PS in Modern French oral narratives, see Carruthers (2005) and Caudal (2010). It is telling that the PS mostly shows in 'patrimonial', high-register narratives - these are closest to its still abundant literary uses. The PS is otherwise still found in conversational narratives, but mostly formulaic \& pivotal functions.

${ }^{6}$ This evaluation is based on a quick quantitative assessment I conducted on 500 randomly selected inflected verb extracted forms the Frantext Classical French sub-corpus.
} 
One can surmise that this evolution is connected to the fact that the PC developed a full perfective semantics Middle French / Renaissance French, i.e. some time after the $14^{\text {th }}$ century. See Caudal (2015a) and Treikelder (2006) for a detailed study of this 'perfectivisation' process; the key observations are that:

(i) The PC was not compatible with past temporal modifiers until the $15^{\text {th }}$ century, ${ }^{7}$ and (ii) It was not capable of unconstrained sequence-of-event readings prior to the $15^{\text {th }}$ century. It seems intuitively natural that without such past perfective features, the PC could not have developed inchoative interpretations of state-denoting utterances - that its inchoative capability was still relatively new in the $17^{\text {th }}-18^{\text {th }}$ century.

3.1. A NOTE ON INCHOATIVE READINGS OF ACTIVITY-DENOTING UTTERANCES. The extent to which predicate-denoting utterances are actually capable of inchoative readings in French is a largely independent empirical question from that of inchoative readings of stative utterances, and a very complex one. I will only say a few words about them here. Some works have hypothesized that inchoative readings of PS/PC-marked activity verbs in the PS are in fact infelicitous in French (e.g., Lab 1994). Although such readings appear to be attested, they are rare in corpora. Their very possibility is largely contingent on how likely it is we can infer a causal subevent bringing about as its result the event type normally described by the utterance and this seems to be gen-erally difficult with most activity utterances, in contrast with stative utterances. ${ }^{8}$ It appears though that less dynamic activities, ${ }^{9}$ i.e., more state-like activity verbs such as dormir 'sleep', can more readily receive inchoative readings, cf. (13).

(13) Mais, si petite que soit la consolation, elle berce. Gilbert dormit bientôt ; la nuit passa. (Frantext - BAZIN René, Le Blé qui lève, 1907, p. 125)

'But no matter how small the consolation, it rocks. Soon, Gilbert slept-PS; the night went by.'

Moreover, most of the - seemingly rare ${ }^{10}$ - occurrences I found in the Frantext corpus appear to have a durative reading, involving an implicit, cognate inner argument or some implicit measure modifier, cf. (14) where the sequence of event context makes it obvious. Durative readings are also facilitated when the VP is marked with a manner adverbial: thus in (15), the swimming event described is not a bona fide inchoative - it is a durative event of swimming.

(14) Il dormit, puis il s'éveilla... (Frantext, GIONO Jean - Que ma joie demeure (1934, p. 492) 'He slept-PS, then he woke-PS up...'

(15) Quand elle [l'eau] atteignit son ventre, il se coucha doucement sur elle et nagea à grandes brasses silencieuses. (GIONO Jean, Naissance de l'Odyssée, 1938), p. 94)

'When the water reached-PS his belly, he lay-PS gently on top of it, and swam-PS in great silent fathoms'.

\footnotetext{
${ }^{7}$ In fact, the PC became compatible with certain recent past temporal modifiers as late as the $17^{\text {th }} / 18^{\text {th }}$ century, such as e.g. hier, 'yesterday'; cf. Caudal \& Vetters (2007).

${ }^{8}$ One can hypothesize that stative utterances having a stative denotation, they can easily be promoted to a resultant stative meaning; not so with activity utterances.

${ }^{9}$ This kind of contrast reveals how little we know, in fact, about the complexity of the actantial and aspectual profiles of so-called activity- and state-denoting utterances.

${ }^{10}$ This paper remains work in progress: obviously, in order to quantify the frequency of activity-denoting utterances in Modern French, one would need a dedicated corpus study.
} 
3.2. INCHOATIVE STATIVE PS IN MODERN FRENCH. Let us turn now to inchoative readings of stative utterances in Modern French. Strikingly enough, inchoative coercion with the PS and the PC seems to remain problematic with certain kinds of stative predicates - such difficulties were never discussed in coercion-oriented analyses of Modern/Contemporary French tenses, to the best of my knowledge. To establish a baseline for this study, note that there seems to be nearly twice as many tokens of etre in the PS, than of être in the PC $(124,288$ vs. 72,250$) .{ }^{11}$ As we will see below, this does not explain the stark statistical differences between the two tenses in terms of their distribution with stative utterances in the Frantext Modern French corpus.

Intuitively, in Modern French, inchoative readings of individual-level stage predicates can be problematic, if they are not associated with a contextual or formal cue (e.g. constructions enforcing a transitional, change-of-state reading) supporting the change-of-state they convey. Thus, while (16) and (17) are perfectly fine given that relative clauses are well-known means of enforcing sequence-of-event readings, the same PS forms in matrix clauses cannot have an inchoative reading 'out of the blue'. According to my judgement, (18) only has some kind of 'experiential perfect'-like reading, and has an archaic, Renaissance/Classical French feel to it.

(16) Napoléon Bonaparte, le jour où il fut empereur (be emperor-PS.3sg). (Official radio show of the Académie Française, 01/01/2005, with C. Dickès and J. Tulard, https://www.canalacademie.com/ida346-Napoleon- Bonaparte-le-jour-ou-il-fut-empereur.html) 'Napoléon Bonaparte, on the day he became-PS.3sg Emperor...'

(17) Il le laissa en l'abbaye et s'en retourna à Constantinople, où il fut empereur et prit la couronne (...). (Guizot, Collection des mémoires relatifs à l'histoire de France, 1824, Brière, Paris, p.33)

'He left him in the abbey, then went back to Constantinople, where he became-PS.3sg emperor'.

(18) \#Napoléon Bonarparte/Il fut-PS.3sg empereur. (no inchoative reading; experientiallike reading)

'Napoléon Bonaparte/He has been Emperor'.

Furthermore, still following my intuition, it seems that the PC is much less inclined to having such individual-level inchoative readings, with (19)-(20) or without (21) supporting context.

(19) Napoléon Bonaparte, le jour où */??il a été-PC.3sg empereur.

(20) Il le laissa en l'abbaye et s'en est retourné à Constantinople, */??où il a été-PC.3sg empereur.

(21) \#Napoléon Bonaparte/Il a été (be emperor-PC.3sg) empereur. ( ${ }^{O k}$ existential/*inchoative)

In order to assess whether these intuitions were founded, I extracted all être-PS $N$ and être-PC N constructions in the Frantext Modern French sub-corpus; obtaining respectively 1452 and 1054 utterances. I then removed noise (mostly passives) in the the être-PS $N$ set, and randomly

\footnotetext{
${ }^{11}$ Note that since the corpus is not morphologically tagged for inflection, the number of PS tokens is probably overestimated. Indeed, PS forms are sometimes orthographically (and misleadingly) identical in the corpus with subjonctif imparfait forms, since diacritics are not always correctly encoded: thus, some fut (PS-3sg) forms are incorrect spellings for fût (subjonctif imparfait, 3sg). Given the abundance of third singular forms (95790), it could well be that the actual number of tokens of être in the PS is, in fact, lower than here indicated.
} 
selected 508 bona fide active être-PS $N$ structures (a ratio of roughly $17 \%$ noise). From the other set, I also removed noise and randomly selected 508 bona fide active être-PC $N$ structures.

I then proceeded to annotate each set of utterances semantically, setting apart seemingly 'productive' inchoative readings from syntactic constructions, which generally have an achievement/change-of-state meaning - i.e. are formerly inchoative stative utterances but with a complex entrenched syntactic structure attached to them, cf. e.g. X être-PS/PC cause de NP event description-Y / que $S$ 'X caused some event $Y$ ', il être-PS/PC de INFY / NPevent description- $Y$ '(contextual speaker) talked about $Y$ ), ce être- $P S / P C$ chose faite (quand...) 'the deed was done (when...)', $I N F_{Y}$ être-PS/PC aisée/difficile (pour X) 'it was easy/hard for $\mathrm{X}$ to do $\mathrm{Y}$ '.

In the PS set, 157 utterances turned out to be some sort of durative anterior past description, purely perfective or with some 'anterior existential' meaning (i.e. almost perfect-like), 65 where some sort of equative structure (e.g. le premier fut $N P$ 'the first was NP', ce fut NP qui 'it was NP who'), for which être appears to contribute some higher-level, 'change-of-theme' function (of a more abstract kind), and 175 had a clear, lexical inchoative stative meaning - a significant proportion, but this was not unexpected as être $N$ are lexically stative. Out of these 175 utterances, 102 were stage-level stative utterances, and 72 were individual-level stative utterances. ${ }^{12}$ The remaining set of relevant utterances were 112 constructions with a lexicalized non-inchoative meaning - generally an activity meaning. Those proportions are by themselves interesting, though difficult to interpret: this pattern, although a priori biased towards individual-level readings, yielded 'only' 14,54\% individual-level inchoative readings, vs. 20,24\% of stage-level inchoative readings - the majority of uses being non-inchoative.

\begin{tabular}{lcccccc}
\hline $\begin{array}{l}\text { Type of } \\
\text { structure }\end{array}$ & $\begin{array}{c}\text { Durative } \\
\text { anterior }\end{array}$ & $\begin{array}{c}\text { Equative } \\
\text { structure }\end{array}$ & $\begin{array}{c}\text { Lexicalized } \\
\text { construction }\end{array}$ & $\begin{array}{c}\text { Stage-level } \\
\text { inchoative }\end{array}$ & $\begin{array}{c}\text { Individual-level } \\
\text { inchoative }\end{array}$ & Total \\
\hline Occurrences & 158 & 65 & 153 & 60 & 72 & 508 \\
\hline Percentages & $31.10 \%$ & $12,8 \%$ & $30.12 \%$ & $11.81 \%$ & $14.17 \%$ & $100 \%$ \\
\hline
\end{tabular}

Table 3. Etre-PS $N$ structures extracted from the Frantext Modern French corpus

But the crucial point is that none of the 73 instances of individual-level inchoative involve a 'bare' matrix sentence, without any contextualizing temporal modifier cf. (22), or another sequence-of-event reading-facilitating device. These comprise relative clause structures (23), overt bi-clausal causo-temporal structures (quand/lorsque/dès que... 'when/as soon as...'), causo-temporal discourse connectives (including et 'and') (24), temporal aspectuo-modifiers (e.g. à partir de ce moment 'from that moment on'), and manner adverbials correlating with e.g. surprise/suddenness (e.g. brusquement 'abruptly'). The only examples which prima facie qualify as such, actually involve clear discourse structural patterns - i.e. at least two instances of 'bare' matrix clauses constituting a sequence of events, (25).

(22) Il le fit chef d'escadron ; en 1849, ce chef d'escadron fut-PS.3sg lieutenant-colonel (...)

(HUGO Victor, Histoire d'un crime : Déposition d'un témoin, 1883, p. 310)

'He made him squadron leader; in 1849, this squadron leader became a lieutenant-colonel.'

(23) Il la suivit à Creuzburg, où elle fut-PS.3sg mère pour la première fois (MONTALEMBERT Charles, Histoire de sainte Elisabeth de Hongrie, 1836, VI)

'He followed her to Creuzburg, where she became a mother for the first time'

1225 of these 72 lutterances are potentially also durative perfective; but the inchoative meaning is most salient. 
(24) Les choses suivant leur cours naturel, Talou devint empereur du Ponukélé, et Yaour futPS.3sg roi du Drelchkaff. (ROUSSEL Raymond Impressions d'Afrique, 1910, p. 166)

(25) Quand vint le Directoire, époque à laquelle Malin régnait dans les conseils de la République, les ventes furent réalisées au nom de Malin. Grévin fut-PS.3sg notaire et Malin fut-PS.3sg conseiller d'État. Grévin fut-PS.3sg maire d'Arcis, Malin fut-PS.3sg sénateur et comte de Gondreville. (BALZAC Honoré de, Le Député d'Arcis,1850, p.767)

'When the Directoire came, when Malin reigned in the councils of the Republic, the sales were made in Malin's name. Grévin became a notary and Malin became a State Councillor. Grévin became mayor of Arcis, Malin became senator and count of Gondreville.'

The above discursive sequence involves a string of discourse segments attached to each previous segment via the SDRT rhetoric (Asher \& Lascarides 2003) Narration. As suggested in Caudal \& Vetters (2006), discourse relations for are structurally equivalent to 'silent' discourse connectives, and such discourse structural patterns are strong instances of supporting contextual cues.

In contrast, the stage-level inchoative structures found did incorporate discursive sequences with 'bare', unmodified etre-PS utterances, and without supporting discourse structural cues. Thus in (26), the attachment segment for Le château fut-PS.3sg sens dessus dessous is a 'backgrounded' utterance ( $C$ 'était en effet la crise salvatrice) - it does not follow another Narrationintroduced segment, unlike what I found to be the case for individual-level inchoative utterance. This even clearer in (27), where the relevant segment follows reported speech - and is therefore not evidently part of a strongly sequence-of-event inducing context.

(26) Brusquement, Blanche comprit ce qui se passait : l'enfant urinait tant qu'elle pouvait. C'était la détente ! Vite, la température ! (...) C'était en effet la crise salvatrice. Le château fut-PS.3sg sens dessus dessous. (ARAGON Louis, Les Voyageurs de l'impériale, 1947, p. 297)

'Suddenly, Blanche understood what was happening: the child was urinating as much as she could. The illness was relaxing its grip! Quick, the temperature! (...) That was indeed the saving crisis. The castle was turned upside down.'

(27) Ainsi, après bien des incidents (...), ainsi finit cette dispute." M Arnauld, nous dit Fontenelle, fut-PS.3sg vainqueur dans son parti (...). (SAINTE-BEUVE Charles, Port-Royal, t. 5,1859, p. 280)

'Thus, after many incidents (...), so ends this argument."Mr Arnauld, Fontenelle tells us, was the winner in his party.'

Let us turn now to the être- $P C$ part of this corpus study. After removing noise from the extracted etre- $P C N$ structures, I randomly selected and annotated 508 utterances. The overall constitution of this sample turned out to be very different, quantitatively, cf. Table 4:

\begin{tabular}{lccccccc}
\hline $\begin{array}{l}\text { Type of } \\
\text { structure }\end{array}$ & $\begin{array}{c}\text { Perfect- } \\
\text { like }\end{array}$ & $\begin{array}{c}\text { Durative } \\
\text { anterior }\end{array}$ & $\begin{array}{c}\text { Equative } \\
\text { structure }\end{array}$ & $\begin{array}{c}\text { Lexicalized } \\
\text { construction }\end{array}$ & $\begin{array}{c}\text { Stage-level } \\
\text { inchoative }\end{array}$ & $\begin{array}{c}\text { Individual- } \\
\text { level inch. }\end{array}$ & Total \\
\hline Occurrences & 256 & 11 & 4 & 221 & 7 & 9 & 508 \\
\hline Percentages & $50.29 \%$ & $2.17 \%$ & $0.8 \%$ & $43.5 \%$ & $1.4 \%$ & $1.8 \%$ & $100 \%$ \\
\hline
\end{tabular}

Table 4. Etre-PC N structures extracted from the Frantext Modern French corpus 
The different proportions of inchoative utterances (16 vs. 132 out of 508) is significant - especially since out of these utterances, only 6 individual-level inchoatives and 4 stage-level inchoatives are clearly deprived of any perfect meaning. Compare (28) and (29):

(28) ...moi j'ai été-PC.1sg toucheur de boeufs aussitôt que j'ai su marcher. (Frantext corpus, SAND George - La Mare au diable, 1846, p. 64)

'I've been a cowboy ever since I could walk/I became a cowboy as soon as I could walk'

(29) Quand le fils du père Génin est revenu, il est allé droit sur lui et tout de suite ils ont étéPC.3pl amis (...). (GIONO Jean, L'eau vive, 1943, p. 370)

'When Genin's son came back, he went straight for him and right away they were friends.'

Even more striking is the near absence of 'durative perfective' and 'equative structures' in the PC set; although these are syntactically more abstract than bona fide inchoative event descriptions associated with 'lexical' uses of être $N$, they are nevertheless some kind of 'change-ofstate' structure as well. This might suggest that there are constructional, i.e. arbitrary conventionalized differences in the way the PC and PS can associate with inchoative readings. And unsurprisingly, perfect-like uses, especially so-called 'existential' readings ( 242 utterances out of the 256 utterances having a perfect-like, resultative meaning), get the lion's share in this sub-corpus. It could be suggested that être $N$ structures are naturally biased towards such readings given that the PC is the only tense in Modern French capable expressing such readings. And strikingly, all the inchoative readings found for être- $P C N$ were associated at least with some supporting linguistic cues, plus a change-of-state reading inducing discourse structural context. Given the paucity of these findings however, this needs to be checked against a larger corpus study.

To conclude the quantitative part of this study, let us turn now to stative utterances pertaining to the wide semantic domain of space. A quick foray into the Frantext corpus revealed another striking difference between the PC and the PC in this respect. I extracted two distinct series of spatial expressions: posture-related stative structures, composed from être plus a deverbal adjective (être assis 'seated', être agenouillé 'kneeling/crouching', être allongé/couché 'lying', être debout 'standing'. The results are quite telling. Etre-PS posture- $A D J$ yielded only 67 occurrences, 54 of which are inchoative, and 13 have some other kind of reading ( 9 are durative, and 4 anterior existential). All of the 54 inchoative utterances are either associated with an overt adverbial forcing a change-of-state interpretation (18 utterances) or a biclausal structure enforcing a strict causo-temporal ordering between two events (e.g. lorsque/quand P, $Q$ 'when P, Q'). And crucially, removing this supporting material invariably blocks the inchoative reading, and can force an altogether different reading, cf. (30). So, posture inchoatives align with individual-level inchoatives in this respect (cf. 18 above).

(30) M. De Charles fut-PS.3sg bientôt assis à côté de Mme Swann. (PROUST Marcel, À la recherche du temps perdu. 8. Du côté de Guermantes 1,1920, p. 267)

'Soon, Mr. De Charles sat down next to Mrs. Swann.'

(30') \#M. De Charles fut-PS.3sg assis à côté de Mme Swann. ( ${ }^{\mathrm{OK}}$ pass., ${ }^{\mathrm{OK}}$ durat., *inchoative)

In contrast, être- $P C$ posture- $P P$ only yielded 16 instances, with a mere 7 inchoative readings ( 5 with a biclausal causo-temporal structure, and 2 with the connective puis 'then'). We find, again, a disproporition similar to that observed with inchoative individual-level states - and the necessity of support material, cf. (31) vs. (31'). 
(31) Il remit ses souliers sans se presser (...). Puis il a été debout. (RAMUZ Charles-Ferdinand, La Grande peur dans la montagne, 1926 ; p.214)

'He put his shoes back on without hurrying (...). Then he stood up.'

(31') \#Il a été debout. ( ${ }^{\mathrm{OK}}$ resultative, *inchoative)

A similar extraction of être-PS + spatial preposition $/ A D V^{13}$ structures vs. être- $P C+$ spatial preposition/ADV yielded even more marked results in terms of disproportion, and necessity of the supporting material - with a large proportion of the être- $P C$ construction being periphrastic 'go' constructions, cf. (32) - such constructions date back to at least the Old French period.

(32) Vous avez été-PC.2sg à Ferrare ! Moi qui vous y ai tant cherché ! (STENDHAL, La Chartreuse de Parme, 1839, p. 205)

'You went to Ferrara! I looked for you there so much!'

Note that in Old French, the PS already had a limited coercive capability with such locative statives, and also required supporting material, cf. (33).

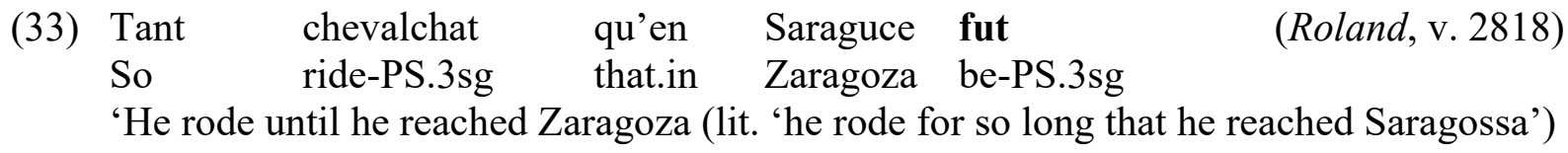

But most importantly, this study revealed the existence of a novel class of stative inchoative uses of the PS in Modern French ( $>19$ th c.). It combines a non-perceived or poorly perceived change of location with a sudden cognitive update; the agent's perception of the change of location is thus 'gappy'; I will dub it this special use the 'consciousness lapse' PS, cf. (33-34).

(34) Et il [Rouletabille]poussa la porte. (...)Nous fûmes-PS.1pl dans le vestibule de la Tour. L'obscurité était à peu près complète. (LEROUX Gaston, Le Parfum de la dame en noir, 1908, p.107)

'And he pushed open the door. [... ] We entered (lit. 'we started being in') the vestibule of the Tower. The darkness was almost complete.'

(35) Je roulai vers le nord et traversai la rivière, pénétrai dans Pasadena, traversai Pasadena et, presque immédiatement, je fus-PS.1sg dans les orangers. La pluie battante se matérialisait en aiguilles blanches à la lueur des phares. L'essuie-glace arrivait à peine à me laisser un petit coin pour y voir. (VIAN Boris, Le Grand sommeil [trad.], 1948, p. 203) 'I drove north and crossed the river, entered Pasadena, crossed Pasadena, and almost immediately I entered (lit. 'started being in') in the orange groves. The driving rain materialized in white needles in the glow of the headlights. The windshield wiper could barely leave me a corner to see.'

Such readings do not obtain at all with the PC. Note that in (34), no supporting material at all is present - and it can be omitted in (35); this is a consequence inferential nature of this reading.

4. Some formal consequences. I will now spell out some theoretical consequences for formal approaches, of the various corpus analyses I have conducted so far. Let us assume an orthodox view of coercion as a case of semantic type clash-driven meaning extension. I will replicate here

\footnotetext{
${ }^{13}$ This set comprised 20 elements: sur 'on', dans '(with)in', hors 'outside of', sous 'under', devant 'before/in front of', derrière 'behind', à/aux 'at', près 'close', loin 'far', à l'intérieur 'inside', à l'extérieur 'outside', à côté 'close', au-dessus 'above', en dessous 'underneath', proche 'nearby', à l'avant 'at the front', à l'arrière 'at the rear'.
} 
an implementation of aspectual coercion developed in Caudal, Dench \& Rousarie (2012) and Caudal (2015), based on on the Type Composition Logic (TCL) framework (Asher 2011). The relevant properties of TCL are that it involves a sortal, ontological hierarchy of semantic types on top of the usual logical types, and a selectional restriction 'stack' argument $\pi$, which is essentially used to resolve (and percolate, if need be) selectional restriction during type composition (functional application). Thus, if (36) is the denotation of the PS, it cannot take (37) (a stagelevel stative) as its argument: the combination results in a type clash between the selectional restriction of the PS's argument, the and type of the verbal predicate $\left(\pi^{*} A R G_{1}{ }^{B}: C o S \wedge A R G_{1}{ }^{B}\right.$ : StageState)

$$
\begin{aligned}
& \text { passé-simple déf }=\lambda \mathrm{B} \lambda \Phi \lambda \pi^{\prime} \Phi\left(\pi^{\prime}\right)\left\{\lambda \mathrm{e} \lambda \mathrm{y} \lambda \pi\left[\mathrm{B}\left(\mathrm{e}, \mathrm{y}, \boldsymbol{\pi}^{*} \mathbf{A R G}_{\mathbf{1}}{ }^{\mathrm{B}}: \mathbf{C o S}\right) \wedge \tau(\mathrm{e})<\mathrm{n} \wedge \tau(\mathrm{e}) \subseteq \mathrm{t}\right]\right\} \\
& \lambda \mathrm{e} \lambda \mathrm{x}_{1} \lambda \pi_{1} \text { StateP }\left(\mathrm{e}_{1}, \mathrm{x}_{1}, \pi_{1}{ }^{*} \mathrm{ARG}_{1}{ }^{\text {StateP. }}: \text { StageState }\right)
\end{aligned}
$$

In the TCL framework, this sort of type clash can trigger the intervention of a 'bridging function', here introduced between (36) (the denotation of the PS) and (37) (the stative V's denotation), involving a dependent or polymorphic type - i.e., essentially, some sort of contextsensitive, underspecified event predicate. Thus the dependent, polymorphic type $\varphi_{\epsilon}$ (InnerCoS, type $((Q)$, ,ype $(x I))$ in (38) essentially serves to introduce a change-of-state event predicate, such that the stative event predicate normally denoted by the utterance marked with the PS (here assumed to be intransitive), becomes one of its arguments, and de facto, a result state predicate.

$$
\begin{aligned}
& \mathcal{F}_{1}=\lambda \mathrm{Q} \lambda \mathrm{e}_{2} \lambda \mathrm{x}_{1} \lambda \pi_{1} \exists \mathrm{e}_{1}\left[\mathrm{Q}\left(\mathrm{e}_{1}, \mathrm{x}_{1}, \pi_{1}\right) \wedge \varphi_{\epsilon}(\operatorname{InnerCoS}, \operatorname{type}(\mathrm{Q}), \operatorname{type}(\mathrm{x} 1))\left(\mathrm{e}_{2}, \mathrm{e}_{1}, \mathrm{x}_{1}, \pi_{1}\right) \wedge \operatorname{cause}\left(\mathrm{e}_{2}, \mathrm{e}_{1}\right) \wedge\right. \\
& \text { theme } \left.\left(\mathrm{x}_{1}, \mathrm{e}_{1}\right) \wedge \pi_{1} * \mathrm{ARG}_{1} \mathrm{Q}_{\text {S }} \text { StageState }\right]
\end{aligned}
$$

Given this little formal proposal, the above diachronic analyses of inchoative stative interpretations of the PC and PS take on a new dimension if one evokes some already well-known generative power issues with all semantic mismatch approaches to coercion.

The first problem was raised as early as Bonami (2002), and can roughly be summarized as follows: the intervention of $\mathcal{F}_{1}$ is not sufficiently constrained, so that any type mismatch-based model is bound to over-generate. In the case of inchoative readings triggered by the PS and PC, $\mathcal{F}_{1}$ should apply to any predicate of type StageState. But then the analysis is clearly inadequate when confronted with e.g. spatial predicates (stative posture structures, or locative structures involving être and some spatial PP or adverbial). As we have seen, these (stage-level) inchoative readings are not well-formed without additional supporting material; so a simple type-mismatch based solution is not satisfying to account for the data discussed in section §3.2. And arguably, a more general version of $\mathcal{F}_{1}$ encompassing individual-level stative predicates (or a separate $\mathcal{F}_{2}$ bridging function) is not a possible option either, as we have seen that such inchoative readings also require additional supporting material (it is not a matter of an underspecified predicate not being made specific enough, but of sheer interpretability). Whatever mechanism underlies these configurations, it cannot be captured by a simple type-mismatch based approach.

And the diachronic analysis conducted above suggests that type-mismatch based analyses of inchoativity are subjected to yet another, potentially even more serious set of generative power issues. Given that the respective inchoative capabilities of the PC and PS have continuously changed through time, well after their acquisition of 'proper' past perfective readings (i.e. the $15^{\text {th }} \mathrm{c}$. for the PC), it becomes de facto impossible to even consider that their capacity depends on their having a perfective operator as a semantic condition/logical form element included in their compositional semantics. Interestingly, the TCL implementation here sketched could be re- 
interpreted in terms of conventionalized readings,,${ }^{14}$ by treating 'bridging functions' as separate semantic extensions of the PC / PS, e.g. as instances of "layering" (Hopper 1991). Furthermore, bridging functions could also be instances of so-called 'bridging contexts' in the sense of Heine (2003), i.e., temporary moments in the semantic evolution of a form, where it acquires a novel meaning. Sadly, even then, this would not be enough to account for the empirical complexity we touched upon earlier, ${ }^{15}$ given the necessity of supporting material in some cases (and not others, such as the 'consciousness lapse' reading).

5. Conclusion. It is time we concluded this short study, even though it is by no means conclusive. Given the results of the corpus analyses in $\S 2$ and $\S 3$, and the formal discussion in $\S 4$, it is - I think - safe to say that inchoative readings of stative utterances in the PC/PS, are - to some extent at least - matters of established meanings, i.e. are conventional in some sense, and not primarily driven by the necessity to overcome type mismatches, as classic, coercion-based analyses would suggest. This conclusion is supported by the need for what I called 'supporting material', and/or a supporting discourse structural context, in obtaining inchoative readings from individual-level utterances in the PS/PC, as well as locative and posture stative structures in the PS/PC (§3.2). Thus, the relatively novel 'consciousness lapse' inchoative readings of the PS which the PC altogether lacks - appears to be of an arbitrary nature. In addition to this, the distinctly lower frequency (ten times lower, no less) of inchoative readings of the PC with stative locatives and posture structures in Modern French cannot be explained on the basis of type-mismatch analysis. There might not even be any necessity for an aspectual type system to attempt at overcoming type mismatches in the first place, if my analysis of the the Old French data in section 2 is correct: while the Old French PC has a nascent perfective meaning, it seems not to have been able to combine with stative utterances. Why it changed at later stages in the evolution of this tense is probably connected to its gaining a full past perfective meaning; but how it changed is $-\mathrm{I}$ think - yet to be determined. ${ }^{16}$ Yet there is clearly something going in terms of well-established vs. less well-established combinations and readings here; there is far more to tell about this story than the classic coercion doxa can tell. Of course, the notion of supporting material, and its role in semantic composition, remains to be investigated more thoroughly. It is clearly a central parameter in untangling the often complex relationships between tenses, and event structure types. ${ }^{17}$ On a more positive note, my results are certainly in line with independent, earlier findings about complement coercion (see e.g., Katsika et al. 2012 - which was also judged to have at least some conventional dimension.) This, I think, is the path we should follow to find a novel solution to the - now old - problem of so-called 'aspectual coercion'.

\section{References}

Asher, Nicholas. 2011. Lexical meaning in context: A web of words. Cambridge: Cambridge University Press.

Asher, Nicholas \& Alex Lascarides. 2003. Logics of Conversation. Cambridge: Cambridge University Press.

\footnotetext{
${ }^{14}$ As opposed to meanings productively derived from rules in the semantic type system of the metalanguage.

${ }^{15}$ And this might only be the tip of the iceberg; a thorough inventory of stative aspectual classes, and many additional, more in-depth corpus studies, would be required to settle this question.

${ }^{16}$ I believe the relatively recent solution proposed in Caudal (2015a) should be abandoned in the light of the novel data discussed in section $\S 2$; and I am not aware of any other formal analysis of this phenomenon.

${ }^{17}$ Similar effects known are known to arise with e.g. progressives: progressives tend to be less compatible with achievement than accomplishment utterances, but supporting material and/or a supporting context can help.
} 
Bary, Corien \& Markus Egg. 2012. Variety in Ancient Greek aspect interpretation. Linguistics and Philosophy 35(2). 111-134. https://doi.org/10.1007/s10988-012-9113-1.

Bonami, Olivier. 2002. A syntax-semantics interface for tense and aspect in French. In Franck Van Eynde, Lars Hellan \& Dorothee Beermann (eds.), Proceedings of the 8th International Conference on Head-Driven Phrase Structure Grammar. 31-50. Stanford, CA: CSLI.

Carey, Kathleen. 1994. The grammaticalization of the perfect in Old English: An account based on pragmatics and metaphor. In William Pagliuca (ed.), Perspectives on grammaticalization. 103-117. Amsterdam: John Benjamins.

Carruthers, Janice. 2005. Oral narration in Modern French: A linguistic analysis of temporal patterns. Oxford: Legenda.

Caudal, Patrick. 2010. Tense switching in French oral narratives. In Janice Carruthers \& Maeve McCusker (eds.), The "Conte" - Oral and written dynamics. 235-260. Oxford: Peter Lang.

Caudal, Patrick. 2015a. Uses of the passé composé in Old French: Evolution or revolution? In Jacqueline Guéron (ed.), Sentence and Discourse, 178-205. Oxford: Oxford University Press.

Caudal, Patrick. 2015b. Mort d'un passé sous-spécifié, naissance d'un passé perfectif: Évolution du passé simple, 13e-15e siècle. In Anne Carlier, Michèle Goyens \& Béatrice Lamiroy (eds.), Le français en diachronie: Nouveaux objets et méthodes. 373-404. Bern: Peter Lang.

Caudal, Patrick, Heather Burnett \& Michelle Troberg. 2016. Les facteurs de choix de l'auxiliaire en ancien français: Étude quantitative. In Sophie Prévost \& Benjamin Fagard (eds.), Le français en diachronie. Dépendances syntaxiques, morphosyntaxe verbale, grammaticalisation. 237-265. Bern: Peter Lang.

Caudal, Patrick, Alan Dench \& Laurent Roussarie. 2012. A semantic type-driven account of verbformation patterns in Panyjima. Australian Journal of Linguistics 32(1). 115-155. https://doi.org/10.1080/07268602.2012.658740.

Caudal, Patrick \& Carl Vetters. 2006. Les temps verbaux : des connecteurs temporels qui s'ignorent? In Estelle Moline, Dejan Stosic \& Carl Vetters (eds.), Les connecteurs temporels du français (Cahiers Chronos), vol. 15, 105-137. Amsterdam / New York: Rodopi.

Caudal, Patrick \& Carl Vetters. 2007. Passé composé et passé simple : Sémantique diachronique et formelle. In Emmanuelle Labeau, Carl Vetters \& Patrick Caudal (eds.), Sémantique et diachronie du système verbal français (Cahiers Chronos), vol. 16. 121-151. Amsterdam \& New York: Rodopi.

Condoravdi Cleo \& Deo Ashwini. 2015. Aspect shifts in Indo-Aryan and trajectories of semantic change. In Chiara Gianollo, Agnes Jäger \& Doris Penka (eds.), Language change at the syntax-semantics interface. 261-292. Berlin: Mouton De Gruyter.

Foulet, Lucien. 1920. La disparition du prétérit. Romania 46. 271-313.

Garey, Howard B. 1957. Verbal Aspect in French. Language 33(2). 91-110. https://doi.org/10.2307/410722.

Haverling, Gerd V. M. 2010a. Actionality, tense, and viewpoint. In Pierluigi Cuzzolin \& Philip Baldi, (eds.), New perspectives on historical Latin syntax, vol. 2, Constituent syntax: adverbial phrases, adverbs, mood, tense. 277-523. Berlin: Mouton de Gruyter.

Haverling, Gerd V. M. 2010b. Sur l'expression du temps et de l'aspect grammatical en latin tardif. De Lingua Latina 3(5). 1-23.

Heine, Bernd. 2003. Grammaticalization. In Brian D. Joseph \& Richard D. Janda (eds.), The handbook of historical linguistics. 573-601. Oxford \& Malden, MA: Blackwell. 
Hopper, Paul J. 1991. On some principles of grammaticization. In Elizabeth Closs Traugott \& Berndt Heine (eds.), Approaches to grammaticalization: Volume I. Theorectical and methodological issues. 17-36. Amsterdam \& Philadelphia: John Benjamins.

Kamp, Hans \& Christian Rohrer. 1983. Tense in texts. In Rainer Bäuerle, Christoph Schwarze \& Arnim von Stechow (eds.), Meaning, use, and interpretation of language. 250-269. Berlin: Walter de Gruyter.

Katsika, Argyro, David Braze, Ashwini Deo \& Maria Mercedes Piñango. 2012. Complement coercion - Distinguishing between type-shifting and pragmatic inferencing. The mental lexicon 7(1). 58-76. https://doi.org/10.1075/ml.7.1.03kat.

Krifka, Manfred. 1998. The origins of telicity. In Susan Rothstein (ed.), Events and grammar. 197-235. Dordrecht: Kluwer.

Lab, Frédérique. 1994. Traduire le prétérit: Imparfait ou passé simple? Linguistique contrastive et traduction 3. 57-85.

Martin, Robert. 1971. Temps et aspect: Essai sur l'emploi des temps narratifs en moyen français. Paris: Klincksieck.

Moens, Marc \& Mark Steedman. 1988. Temporal ontology and temporal reference. Computational Linguistics 14(2). 15-28.

Smith, Carlota. 1991. The parameter of aspect. Dordrecht: Kluwer.

Swart, Henriëtte de. 1998. Aspect shift and coercion. Natural Language \& Linguistic Theory 16(2). 347-385. https://doi.org/10.1023/A:1005916004600.

Treikelder, Anu. 2006. Le passé composé de l'ancien français: Sémantique et contexte. Tartu: Tartu University Press.

Wilmet, Marc. 1970. Le système de l'indicatif en moyen français: Étude des "tiroirs" de l'indicatif dans les farces, sotties et moralités françaises des XVe et XVIe siècles. Geneva: Librairie Droz. 